\title{
SISTEM INFORMASI IVENTORY DAN PEMINJAMAN BARANG PADA LABORATORIUM PROGRAM STUDI SISTEM KOMPUTER
}

\author{
Rifky Rajendra ${ }^{1)}$, Kodrat Imam Satoto ${ }^{2)}$, Rinta Krida Lukmana ${ }^{2)}$ \\ Jurusan Teknik Sistem Komputer, Fakultas Teknik, Universitas Diponegoro \\ Jl. Prof. Sudharto, Tembalang, Semarang \\ email : rifky.rajendra@gmail.com
}

\begin{abstract}
Information technology development today resulted in the growing number of internet users. Easy access of the internet makes it as a media presentation of data to both individuals and institutions. It is similar with Computer System major that has taken advantage of the Internet to provide a variety of information to both academic and community service in the field of information technology. But it is still using manual method to organize and inventory data associated with inventory and borrowing system of lab in a site. One way to ease the data organization is to design an information system that can record and organize all the data held by the Computer System.

Design and Implementation phase begins with system requirement analysis. Its objection is to get a proper system specification. In design phase, Data Flow Diagram is used to represent data in a logic way. The result from design phase then implements with PHP programming language, associated with Database Management System MySQL, and Javascript to generate a dynamic web-based information system.

System Information inventory and Loan goods on the laboratory computer system, has two categories of access rights, there are super admin and admin (operator), where the super admin have all permissions and the lending system inventory information communications system laboratory, while the operator is further divided into three parts ie (embedded, networking, and software engineer) where each lab has one operator and one other can not access that does not belong to its access. The test results and Loan Information Systems Inventory Computer Systems Laboratory, showed that all the features of the application can work well as Super Admin can see the entire menu of each Lab and can make the process of printing from any lab reports, for each lab operator can to process the data change, the process of borrowing items and returns. Using the Entity Relationship Diagram modeling system. The information systems have as many as four users on the system, which are super admin, operator Lab embedded, networking lab operator, operator Lab Engineer software.
\end{abstract}

Keywords : web-based information system, PHP, MySQL, Javascript

\section{BAB I}

\section{PENDAHULUAN}

\subsection{Latar Belakang}

Perkembangan Ilmu Pengetahuan dan Teknologi yang semakin komplek mampu mempengaruhi pola pikir manusia. Kemajuan ini telah mendorong manusia untuk berusaha mengatasi segala permasalahan yang timbul di sekitarnya. Terutama dalam bidang akademik. Pemrosesan basis data menjadi perangkat andalan yang kehadirannya sangat diperlukan oleh berbagai institusi dan perusahaan. Basis data tidak hanya mempercepat dalam memperoleh informasi, tetapi juga dapat meningkatkan pelayanan kepada pelanggan sehingga efektifitas waktu dapat dimaksimalkan, dalam hal ini yaitu memasukan data barang-barang, serta untuk mencatat siapa sajakah yang sedang meminjam barang yang ada di Laboratorium Sistem Komputer Undip. Teknologi yang digunakan untuk mendata informasi tersebut masih bersifat manual dan sederhana, yaitu menggunakan Microsoft Office Excel. Berkembangnya teknologi dalam bidang informasi saat ini, maka sistem yang lama tersebut semakin tertinggal dan sulit digunakan untuk membagi data tersebut untuk keperluan pihak-pihak lain. Program Studi Sistem Komputer

1) Mahasiswa Teknik Sistem Komputer Undip

2) Dosen Teknik Sistem Komputer Undip membutuhkan sebuah sistem informasi yang mudah digunakan dan lebih baik untuk menyebarkan data tersebut. Untuk itu dapat digunakan sebuah sistem informasi berbasis web yang dapat menyebarkan data tersebut secara luas dan mudah diakses melalui jaringan internet. $W e b$ sistem informasi tersebut nantinya diharapkan dapat menjadi jalan keluar yang baik dalam hal mendata barang-barang yang keluar masuk di Laboratorium Sistem Komputer, serta menampilkan data tersebut jika sewaktu-waktu diperlukan. Sistem informasi ini dibuat menggunakan bahasa pemrograman PHP, sistem basis data MySQL, serta CSS template sebagai framework.

Sistem informasi ini terdapat fitur berupa pesan dan berita, dimana pengguna Sistem informasi ini dapat melihat barang apa saja yang sedang dipinjam ataupun sudah dalam kondisi rusak. Berita yang disampaikan oleh sistem informasi ini berupa data barang apa saja yang ada disetiap laboratorium.

Latar belakang masalah yang diangkat dari adanya kasus kehilangan barang di Lab. Sistem komputer, untuk meminimalisir terjadinya kehilangan seperti ini maka munculah sebuah solusi untuk mengatasi masalah tersebut, yaitu dengan membangun sistem informasi 
berbasis web, dimana nanti fungsinya akan mencatat dan mendata semua barang-barang yang ada disemua Lab.

Siskom. Dan juga SI ini dapat berfungsi sebagai pencatat barang masuk dan keluar dari Lab. Sehingga dapat meminimalisir kehilangan barang, dilain hari kemudian. Sistem ini diharapkan nantinya dapat membantu penanggung jawab Laboratorium Sistem Komputer, dalam mendata barang yang keluar masuk di Laboratorium Undip, Serta menangani peminjaman barang yang dilakukan oleh mahasiswa, missal dalam keperluan penelitian mahasiswa memnijam ipad ataupun barang lainnya. Sistem Informasi ini memiliki interface dimana akan memunculkan alert mengenai barang yang dipinjam lengkap dengan jatuh tempo tanggal pengembalian barang yang seharusnya, serta nomor telepon yang dapat dihubungi dari si peminjam.

\subsection{Rumusan Masalah}

Berdasarkan uraian latar belakang, dapat dirumuskan permasalahan yang dihadapi, yaitu bagaimana membangun aplikasi SI yang mana dapat membantu penanggung jawab Laboratorium dalam bertanggung jawab untuk menjaga dan merawat barang-barang yang ada di dalam Laboratorium Sistem Komputer Undip.

\subsection{Pembatasan Masalah}

Pembahasan pada Tugas Akhir ini, masalah dibatasi sebagai berikut :

1. Program aplikasi yang dibuat merupakan rancangan awal sistem informasi yang ditujukan untuk memasukkan dan menampilkan data inventaris barang-barang dan menampilkan peminjam barang yang ada di Laboratorium Sistem Komputer.

2. Bahasa pemrograman yang digunakan adalah PHP 5.2.5

3. Basis data yang digunakan adalah $M y S Q L$ 5.0.51

4. Web Server yang digunakan adalah Apache 2.2.6

\section{LANDASAN TEORI}

\subsection{Sistem Informasi}

Sistem informasi adalah sekumpulan komponen pembentuk sistem yang mempunyai keterkaitan antara satu komponen dengan komponen lainnya yang bertujuan menghasilkan suatu informasi dalam suatu bidang tertentu. Dalam sistem informasi diperlukannya klasifikasi alur informasi, hal ini disebabkan keanekaragaman kebutuhan akan suatu informasi oleh pengguna informasi. Kriteria dari sistem informasi antara lain, fleksibel, efektif dan efisien.

Sistem informasi berbasis komputer (Computer Based Information System) terdiri dari komponenkomponen seperti:

17 Perangkat keras (hardware) yaitu perangkat keras komponen untuk melengkapi kegiatan memasukan data, memproses data dan keluaran data.
35 Perangkat lunak (software) yaitu program dan instruksi yang diberikan ke komputer untuk menjalankan sistem.

35 Database yaitu kumpulan data dan informasi yang diorganisasikan sedemikian rupa sehingga mudah diakses pengguna sistem informasi.

35 Telekomunikasi yaitu komunikasi yang menghubungkan antara pengguna sistem dengan sistem komputer secara bersama-sama ke dalam suatu jaringan kerja yang efektif.

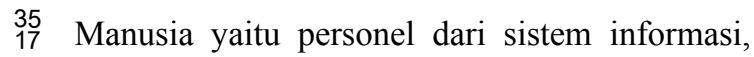
meliputi manajer, analis, programmer dan operator serta bertanggung jawab terhadap perawatan sistem.

35 Prosedur yaitu tata cara yang meliputi strategi, kebijakan, metode, dan peraturan-peraturan dalam menggunakan sistem informasi.[9].

\subsection{PHP (PHP Hypertext Preprocessor)}

PHP adalah bahasa pemrograman yang paling banyak dipakai saat ini. PHP banyak dipakai untuk memrogram situs web dinamis, walaupun tidak tertutup kemungkinan digunakan untuk pemakaian lain.[18]

Model kerja PHP hampir sama dengan HTML, hanya saja dalam prosesnya, saat berkas PHP dijalankan, akan melakkan pengolahan data yang nantinya baru ditampilkan dalam bentuk HTML, berbeda dengan HTML yang hanya menampilkan data tanpa pengolahan. Proses kerja tersebut dapat kita lihat pada gambar 1 berikut.[8]

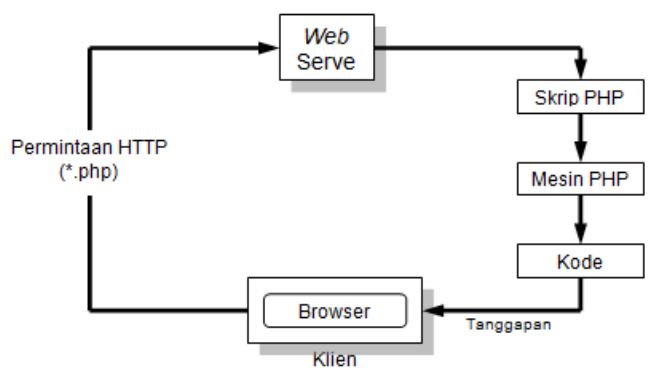

Gambar 1. Diagram proses kerja PHP

\subsection{MySQL}

MySQL adalah Relational Database Management System (RDBMS) yang didistribusikan secara gratis dibawah lisensi GPL (General Public License). Dimana setiap orang bebas untuk menggunakan MySQL, namun tidak boleh dijadikan produk turunan yang bersifat closed source atau komersial.

MySQL sebenarnya merupakan turunan salah satu konsep utama dalam database sejak lama, yaitu SQL (Structured Query Language). SQL adalah sebuah konsep pengoperasian database, terutama untuk pemilihan atau seleksi dan pemasukan data, yang memungkinkan 
pengoperasian data dikerjakan dengan mudah secara otomatis. [10]

\section{BAB III \\ PERANCANGAN SISTEM}

\subsection{Analisis Kebutuhan Sistem}

Seringkali terjadi kesalahan maupun ketidaksepahaman antara sistem yang dibuat dengan keinginan dari pengguna sistem. Misalkan saat ini pegawai TU masih menggunakan administrasi data inventaris secara semi manual, maka akan terjadi kesalahpahaman antara barang yang baru masuk, barang keluar, barang dipinjam ataupun barang yang rusak karena dengan menggunaakan metode seperti ini membuat informasi yang diterima menjadi tidak uptodate dan terjadinya ketidakpraktisan. Analisis data telah dilakukan melalui observasi dari lingkungan dimana sistem akan dibangun.

\subsection{Deskripsi Umum}

Secara umum Program Studi Sistem Komputer merupakan program studi yang masih baru di lingkungan Fakultas Teknik, maupun di Universitas Diponegoro. Salah satu informasi yang diperlukan untuk menunjang kerja praktek dan tugas akhir adalah dengan membangun sebuah website yang mampu mengorganisir data mahasiswa yang telah mengambil matakuliah kerja praktek dan tugas akhir. Setelah melakukan wawancara dengan pihak terkait dan melakukan pengamatan langsung terhadap keadaan di Program Studi Sistem Komputer diharapkan website yang dibuat :

1. Mempermudah mengelola data inventaris bagi pihak admin.

2. Menghindari terjadinya kehilangan barang.

3. Memepermudah proses simpan-pinjam, barang pada setiap Laboratorium.

4. Memepermudah proses masuk-keluar barang pada setiap Laboratorium.

5. Mempermudah mahasiswa untuk proses pemijaman barang di Laboratorium.

\subsection{Analisa}

Tahap analisis sistem yang bertujuan untuk menjabarkan segala sesuatu yang nantinya akan ditangani oleh perangkat lunak. Tahapan ini adalah tahapan dimana pemodelan merupakan sebuah representasi dari objek di dunia nyata. Untuk memahami sifat perangkat lunak yang akan dibangun, analis harus memahami domain informasi, dan tingkah laku yang diperlukan. Dalam perancangan perangkat lunak ini, digunakan metode pemodelan Dekomposisi Fungsional.

Kebutuhan rinci untuk memenuhi hal-hal yang telah disebutkan di atas dibagi menjadi dua, yaitu kebutuhan fungsianal dan non-fungsional. Kebutuhan fungsional adalah kebutuhan yang solid harus ada dalam sebuah sistem informasi, dengan kata lain adalah fiture yang dimiliki oleh SI tersebut. Kebutuhan non-fungsional adalah pelengkap dari sebuah SI, dimana kehadiran nonfungsional ini juga penting, seperti interface (tampilan) dan login session. Dalam Sistem Informasi ini dijelaskan sebagai berikut:

\subsubsection{Kebutuhan Fungsional}

Melihat dari tahapan dan disertai dengan keinginan pengguna dalam fitur yang ada dari aplikasi, fungsi yang muncul dikelompokkan menjadi :

a. Fasilitas untuk menampilkan stok barang Lab.

Fiture ini merupakan fiture umum yang dimiliki oleh semua sistem informasi inventory, dimana user dapat melihat barang apa saja yang tersedia di Laboratorium sistem komputer lengkap beserta kondisi barangnya dan spesifikasinya.

b. Fasilitas untuk menampilkan barang apa saja yang sedang dipinjam.

Fiture ini digunankan sebagai pengingat kepada user yang sedang melakukan login, hal ini dimaksudkan secara tidak langsung user diingatkan oleh sistem bahwa ada barang yang sedang dipinjam.

c. Fasilitas untuk menampilkan History peminjaman

Admin dapat mengetahui barang apa, dan siapa yang pernah meminjam. Fungsi ini khusus diperuntukan kepada super admin saja.

d. Fasilitas untuk memasukan data barang Lab.

Selayaknya fiture dalam sistem informasi inventory, sistem harus bisa melakukan proses memasukan barang baru, dan ditampilkan pada stok barng lab.

e. Fasilitas untuk mengurangi data barang Lab

Pada dasarnya fungsi ini adalah fungsi hapus data barang lab, dimana barang yang sudah dalam kondisi rusak, ataupun sudah tudak layak pakai.

f. Fasilitas untuk mencetak

Surat-surat laporan pertanggung jawaban Lab. Dimana fungsi ini khusus diperuntukan kepada super admin saja, yang ditujukan kepada atasan.

g. Pengguna sebagai berikut :

1. Administrator (superadmin) ; dengan login

2. Operator Laboratorium; dengan login

h. Administrator (superadmin) untuk mengelola sistem informasi, mengelola keseluruhan kegiatan yang berlangsung pada setiap Laboratorium

i. Operator Lab. hanyalah bertugas mengelola tiap Lab. Yang di urus sesuai dengan haknya masing - masing (embedded, networking,software engineer)

\subsubsection{Kebutuhan Non-Fungsional}

Kebutuhan non-fungsional merupakan pelengkap 
dari sebuah SI, dimana kehadiran non-fungsional ini juga penting, seperti interface (tampilan) dan login session. Dalam Sistem Informasi ini dijelaskan sebagai berikut:

a. Operasional

Aplikasi mampu diakses oleh bebrapa Komputer dan beberapa admin yang mendapat tugas jaga gilir di setiap laboratorium Sistem Komputer.

b. Keamanan

Penggunaan username dan password dalam form login untuk membedakan level setiap admin yang masuk.

c. Interface / Antar muka

Antar muka pemakai atau user interface adalah bagian penguhubung antara program sistem informasi dengan pemakai. Kebutuhan terhadap antar muka yang diinginkan sebaik mungkin bersifat user friendly, artinya pengguna dapat menggunakan perangkat lunak yang dibuat dengan mudah dan senyaman mungkin untuk mendapatkan suatu informasi yang diinginkan oleh pengguna tersebut. Kebutuhan antar muka (Interface) untuk suatu aplikasi yang dibuat didapatkan dari hasil observasi dari lingkungan dimana sistem akan dibangun.

\subsubsection{Dekomposisi Fungsional}

Dekomposisi fungsional adalah suatu teknik yang digunakan selama perencanaan, analisis dan bentuk menciptakan hirarki fungsional untuk perangkat lunak. Dekompusisi fungsional pada Sistem Informasi Laboratorium seperti terlihat pada Gambar 3.1.

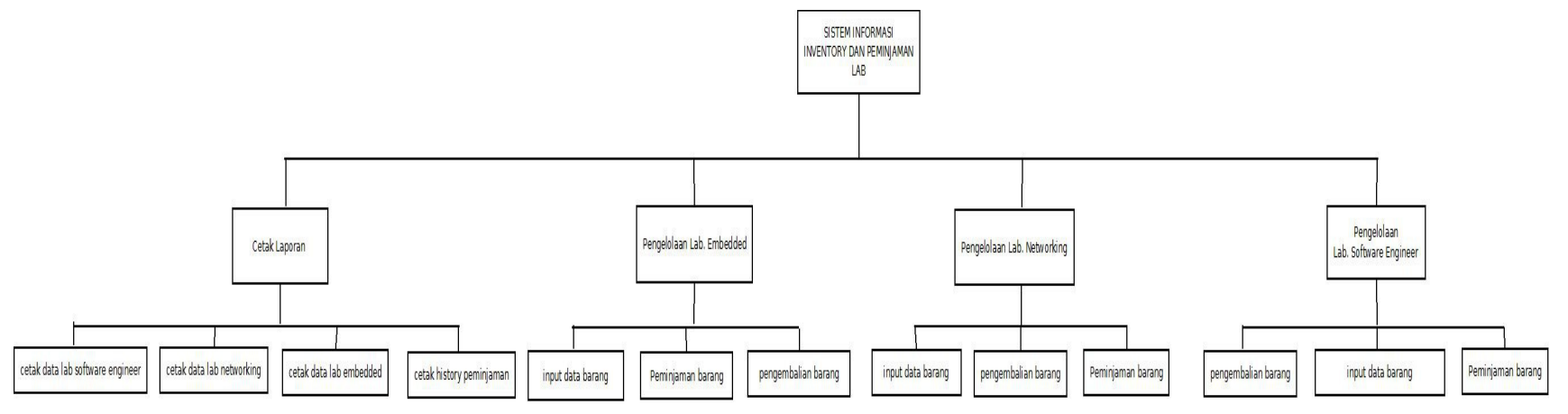

Gambar 3.1 Dekomposisi Fungsional

Gambar 3.1.menunjukan terdapat empat proses (fungsi) diantaranya proses cetak, pengelolaan lab embedded, lab networking, dan lab software engineer, dimana masing-masing proses memilliki detail fungsi. Secara keseluruhan pada sistem informasi ini, admin dibagi menjadi dua kategori, yaitu super admin dan admin(operator). Dimana super admin, dapat melakukan semua transksi disemua Laboratorium yang ada di Sistem Komputer Undip, sedangkan untuk operator laboratorium hanya dapat melakukan transaksi yang menjadi tanggung jawabnya saja.

\subsubsection{Aktor Yang Terlibat}

Aktor yang terlibat pada sistem ini dibagi menjadi dua katergori yaitu : Admin dan Operator Lab, dimana pada poin operator lab, akan dibagi lagi menjadi tiga, yaitu operator lab emenbedded, operator lab, networking dan operator lab software engineer.Deskripisi untuk masing-masing user akan dijelaskan dibawah berikut.

Tabel 3.1 Aktor yang terlibat 


\begin{tabular}{|l|l|l|}
\hline No & \multicolumn{1}{|c|}{ Aktor } & \multicolumn{1}{c|}{ Deskripsi } \\
\hline 1 & SuperAdmin & $\begin{array}{l}\text { SuperAdmin memiliki hak akses tertinggi } \\
\text { untukmengelola data master yang ada dalam } \\
\text { database yaitu data admin dan user, data } \\
\text { barang, data barang dipinjam, history } \\
\text { peminjaman, cetak data dan melihat laporan } \\
\text { transaksi, serta seluruh transaksi pada lab }\end{array}$ \\
\hline 2 & Operator Lab Embedded & $\begin{array}{l}\text { Operator Lab. Embedded. Diantara lain. } \\
\text { lihat alert barang dipinjam, stok barang, } \\
\text { peminjaman, pengembalian, input data, edit } \\
\text { dan data barang. Yang ada pada Lab } \\
\text { Embedded }\end{array}$ \\
\hline 3. & Operator Lab. Networking & $\begin{array}{l}\text { Operator Lab. Networking Diantara lain.; } \\
\text { lihat alert barang dipinjam, stok barang, } \\
\text { peminjaman, pengembalian, input data, edit } \\
\text { dan data barang. Yang ada pada Lab } \\
\text { Networking }\end{array}$ \\
\hline 4. & Operator Lab Sofware & $\begin{array}{l}\text { Operator Lab. Sofware. Diantara Lain.; Ihat } \\
\text { alert barang dipinjam, stok barang, } \\
\text { peminjaman, pengembalian, input data, edit } \\
\text { dan data barang. Yang ada pada Lab } \\
\text { Software }\end{array}$ \\
\hline
\end{tabular}

\subsection{Desain}

Tahap ketiga adalah tahap perancangan perangkat lunak yang merupakan proses multi langkah dan berfokus pada beberapa atribut perangkat lunak. Proses ini menerjemahkan kebutuhan ke dalam sebuah model perangkat lunak yang dapat diperkirakan kualitasnya sebelum dimulainya tahap implementasi. Dalam perancangan model perangkat lunak ini, digunakan metode pemodelan pemrograman terstruktur yaitu DFD (Data Flow Diagram) yang telah menjadi standar dalam industri untuk mengetahui aliran data dalam sebuah program. Metode lainnya adalah Entity Relationship Diagram (E-R Diagram), metode ini menyajikan data dengan menggunakan Entity dan Relationship.

\subsubsection{Diagram Konteks}

Diagram konteks merupakan tingkatan tertinggi dalam diagram aliran data dan hanya memuat satu proses, menunjukkan sistem secara keseluruhan. Semua entitas eksternal yang ditunjukkan pada diagram konteks berikut aliran data-aliran data utama menuju dan dari sistem. Diagram konteks ini tidak memuat penyimpanan data dan tampak sederhana untuk diciptakan, begitu entitas-entitas eksternal serta aliran data-aliran data menuju dan dari sistem.

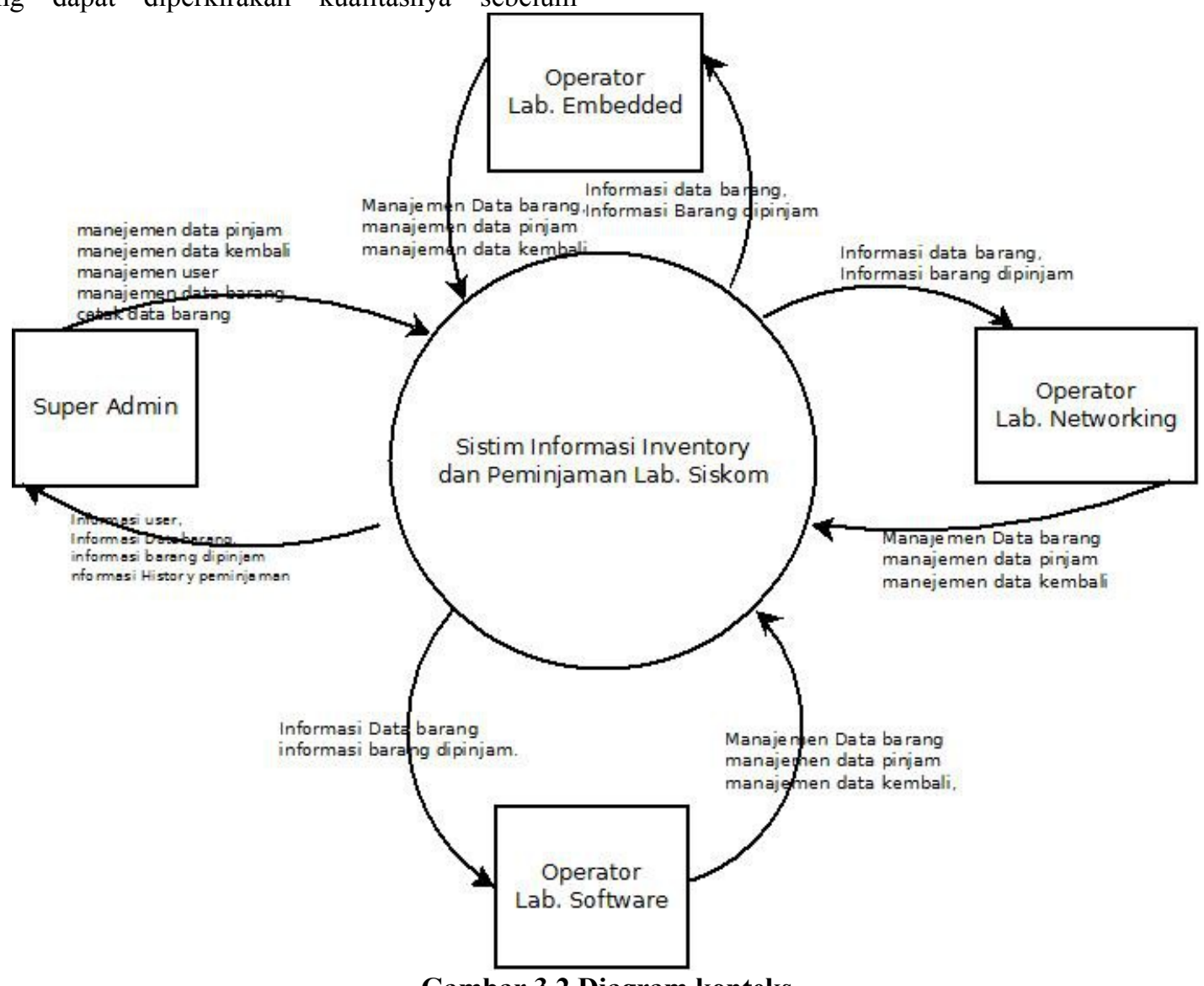

\section{Gambar 3.2 Diagram konteks}

Konteks Diagram seperti terlihat pada Gambar 3.2, dapat dilihat bahwa proses apa saja yang terjadi dalam aplikasi Sistem Informasi laboratorium melibatkan empat sumber atau tujuan data yaitu super admin, operator lab.Embedded, operator lab.

Networking, dan operator lab. Software Engineer.

A. Hak Akses Super Admin

Super Admin memiliki hak akses tertinggi pada sistem informasi inventory ini, dimana super admin dapat melakukan segala transaksi yang ada pada 
sistem informasi ini. Deskripsinya dibawah ini.

1. Super Admin melakukan transaksi simpan pinjam barang pada semua lab Di siskom.

2. Super Admin dapat melakukan editing data inventaris barang baru masuk maupun barang keluar/rusak pada semua lab Di siskom.

3. Super Admin dapat melakukan report laporan tercetak berkala yang ditujukan pada kepala jurusan siskom.

4. Super Admin dapat memanajemen semua alert yang ada pada dalam sistem, alert yang dimaksudkan dalam sistem ini adalah interface pengingat mahasiswa siapa saja yang belum mengembalikan barang Lab.

5. Super Admin dapat Menambah user atau operator masing-masing Lab.

6. Super Admin dapat melakukan cetak data setiap Lab \& history peminjaman.

B. Hak Akses Operator Lab. Embedded

Operator embedded merupakan salah satu dari bagian user, dimana operator ini termasuk pada

kategoti user, namun hanya dapat mengakses pada laboratorium embedded saja. Deskripsinya dibawah ini.

1. Operator Lab. Embedded, melakukan transaksi peminjaman, pengembalian, edit data barang di lab. Embedded Saja.

C. Hak Akses Operator Lab. Networking

Operator Lab Networking merupakan salah satu dari bagian user, dimana operator ini termasuk pada kategoti user, namun hanya dapat mengakses pada laboratorium networking saja saja. Deskripsinya dibawah ini.

1. Operator Lab. Networking, melakukan transaksi peminjaman, pengembalian, edit data barang di lab. Networking Saja

D. Hak Akses Lab Software Engineer

Operator Lab Software Engineeer merupakan salah satu dari bagian user, dimana operator ini termasuk pada kategoti user, namun hanya dapat mengakses pada laboratorium Software Engineer saja. Deskripsinya dibawah ini.

1. Operator Lab. Software Engineer, melakukan transaksi peminjaman, pengembalian, edit data barang di lab Software Engineer Saja

\subsubsection{Data Flow Diagram Level 1}

Data flow diagram menggambarkan sistem sebagai jaringan kerja antar fungsi yang berhubungan satu dengan yang lain dengan aliran dan penyimpanan data. Data Flow Diagram Level 1 seperti terlihat pada Gambar 3.3, memuat proses-proses inti yang ada didalam sistem, berikut gambarnya.

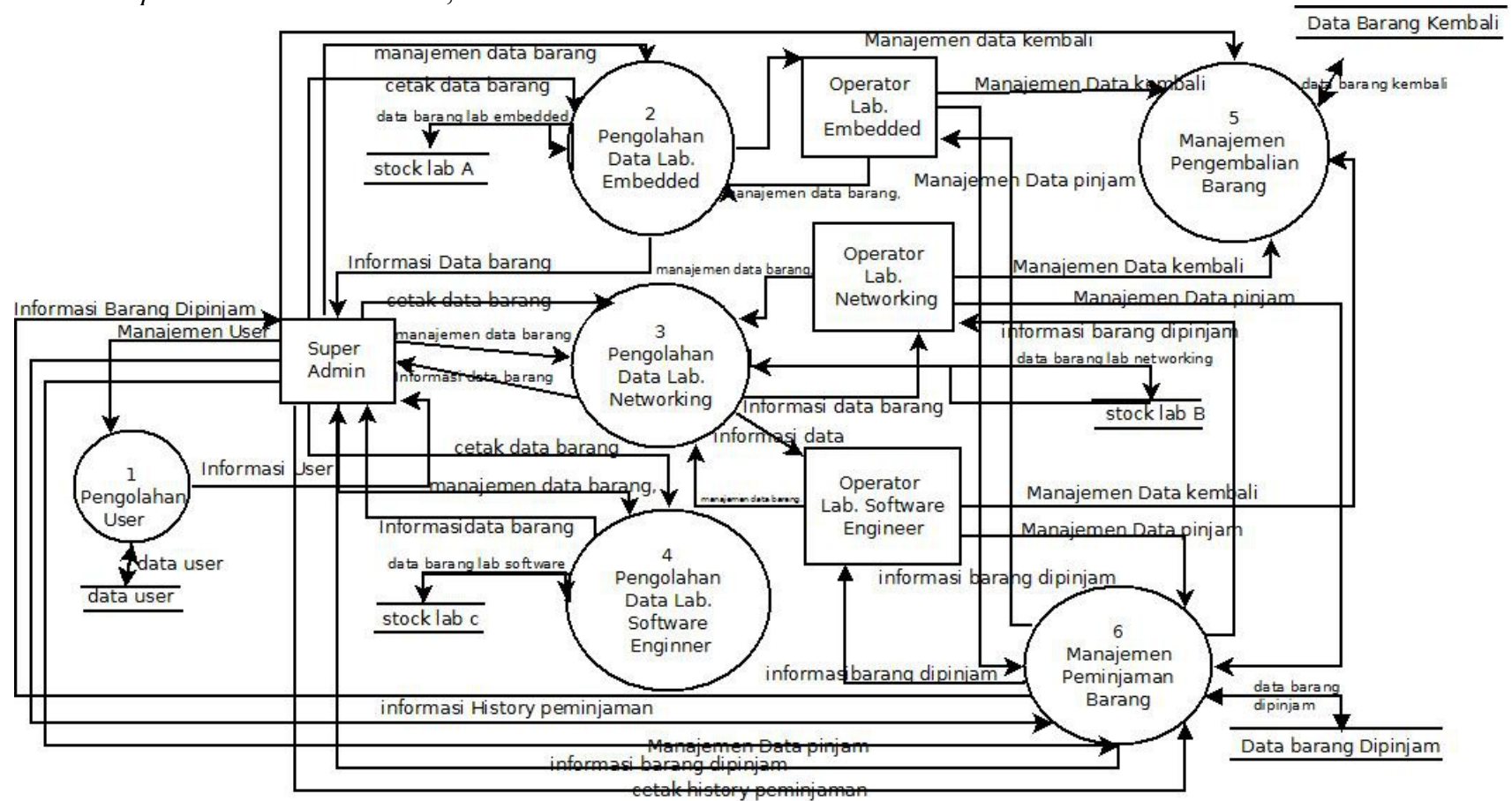

Gambar 3.3 Data flow diagram level 1

Dalam Level 1 Sistem Informasi Inventory dan Peminjaman Lab. Siskom terdapat enam proses yang dilakukan oleh super admin, operator Lab. Embedded, operator Lab. Networking, operator Lab. Software Engineer.

35 Proses 1 yaitu pengolahan user. Admin dapat melakukan fungsi manajemen operator maupun admin, dimana sang superadmin (Admin)-lah yang hanya dapat melakukan manajemen pemberian hak akses kepada tiap-tiap operator lab, sesuai dengan haknya masing-masing yang nantinya data tersebut disimpan dalam basisdata yang ada.

35 Proses 2 yaitu pengolahan data Laboratorium Embedded. Pada pemrosesan data Lab. Embedded, dapat dilakukan oleh dua level admin, yaitu super admin dan Operator Lab. 
Embedded. Melakukan segala macam transaksi yang ada di dalam Lab Embedded, melihat data barang yang dipinjam, memanajemen data barang. Namun SuperAdmin memiliki kelebihan tersendiri, yaitu dapat melakukan manajemen mencetak stock barang, mencetak history peminjaman, hal ini tidak dapat

dilakukan oleh operator Lab. karena soreng operator hanya bertugas sebagai Operator Lab. yaitu, hanya melakukan manajemen data lab. untuk yang bersangkutan dengan perihal cetak mencetak, merupakan hak dan kewajiban dari super admin.

${ }_{17}$ Proses 3 yaitu Pengolahan Data Lab. Networking. Pada pemrosesan data Lab. Networking, dapat dilakukan oleh dua level admin, yaitu super admin dan Operator Lab. Networking. Melakukan segala macam transaksi yang ada di dalam Lab Networking, melihat data barang yang dipinjam, memanajemen data

barang. Namun SuperAdmin memiliki kelebihan tersendiri, yaitu dapat melakukan manajemen mencetak stock barang, mencetak history peminjaman, hal ini tidak dapat dilakukan oleh operator Lab. karena soreng operator hanya bertugas sebagai Operator Lab. yaitu, hanya melakukan manajemen data lab. untuk yang bersangkutan dengan perihal cetak mencetak, merupakan hak dan kewajiban dari super admin.

${ }_{17}^{35}$ Proses 4 yaitu Pengolahan Data Lab. Software Engineer. Pada pemrosesan data Lab. Software Engineer, dapat dilakukan oleh dua level admin, yaitu super admin dan Operator Lab. Software Engineer. Melakukan segala macam transaksi yang ada di dalam Lab Software Engineer, melihat data barang yang dipinjam, memanajemen data barang. Namun SuperAdmin memiliki kelebihan tersendiri, yaitu dapat melakukan manajemen mencetak stock barang, mencetak history peminjaman, hal ini tidak dapat dilakukan oleh operator Lab. karena soreng operator hanya bertugas sebagai Operator Lab. yaitu, hanya melakukan manajemen data lab. untuk yang bersangkutan dengan perihal cetak mencetak, merupakan hak dan kewajiban dari super admin.

${ }_{17}^{35}$ Proses 5 yaitu pengolahan manajemen pengembalian barang, dimana pemrosesan ini dapat dilakukan oleh semua tipe level yang login, namun disesuaikan dengan level loginnya.

${ }_{17}^{35}$ Proses 6 yaitu pengolahan manajemen pengembalian barang, dimana pemrosesan ini dapat dilakukan oleh semua tipe level yang login, namun disesuaikan dengan level loginnya.

\subsubsection{Identifikasi Entitas dan Atribut}

Pada poin 3.3.4 telah dibahas mengenai aktor yang terlibat dalam sistem.
Desain user aplikasi Sistem Informasi yang dibangun akan disederhanakan menjadi dua user, hal ini ditujukan agar sistem yag dibangun menjadi sederhana, karena untuk poin Operator Lab, memiliki hak akses yang sama, namun hanya berbeda laboratorium saja. Hal ini akan dijelaskan seperti dibawah berikut ini.

Berdasarkan pada diagram konteks, desain tabel aktor yang terlibat serta desain dfd yang telah dirancang maka akan dibutuhkan entitas user untuk melakukan proses login, dimana masing-masing user entitas memiliki atribut level admin, agar sistem bisa mengklasifikasikkan, user dengan level Super admin ataupun operator Lab. Pada tahap ini penulis mengklasifikasikan beberapa entitas dan atrbutnya untuk mendesain relasi antar entitas. Dijelaskan dibawah ini:

1. Entitas User dan Atributnya

Tabel 3.3 atribut user

\begin{tabular}{|l|l|}
\hline No & atribut \\
\hline & username*) \\
\hline & Password \\
\hline & Email \\
\hline & fullname \\
\hline & No_hp \\
\hline & level \\
\hline
\end{tabular}

Pada entitas user ini atributnya terdiri dari username. Password email fullname, nomer handphone, dan level masing-masing user untuk masing-masing lab.

2. Entitas Barang dan Atributnya

Berdasarkan dengan diagram konteks. desain dfd yang telah dirancang dan kebutuhan sistem maka akan dibutuhkan entitas barang untuk melakukan proses simpan ataupun proses pinjam. Akan dijabarkan seperti dibawah ini.

Tabel 3.4 atribut barang

\begin{tabular}{|l|l|}
\cline { 2 - 3 } No & Atribut \\
\hline & KodeBarang *) \\
\hline & NamaBarang \\
\hline & spec \\
\hline & TahunBarang \\
\hline & status \\
\hline & nama_image \\
\hline
\end{tabular}

Pada entitas barang ini atributnya terdiri dari username. Kode barang, nama barang, spesifikasi barang, tahun baran gketika dimasukan, status barang apakah baik. Rusak, dipinjam atau ada, dan nama image sebagai data nama barang yang diupload gambarnya. 


\subsubsection{Relasi antar Entitas}

Berdarkan penjabaran entitas, relasi beserta nilai atributnya dan desain dfd, maka sampailah pada tahap perancangan Entity Relationship Diagram dimana tahap ini terdari dari identifikasi relasi dan atribut dan dilanjutkan dengan perancagan erd hal ini adalah salah satu metode pemodelan perangkat lunak yang biasanya digunakan dalam tahap analisis perancangan basisdata. Diagram E-R berupa model data konseptual yang merepresentasikan data dalam suatu organisasi

3.4.4.1.1

Identifikasi Relasi dan

\section{Atribut}

Berdasarkan dengan diagram konteks, desain $d f d$ yang telah dirancang dan kebutuhan sistem, maka akan dibutuhkan relasi antar entitas untuk melakukan transaksi peminjaman barang dan pengembalian barang. Pada tahap identifikasi relasi ini penulis mengklasifikasikan beberapa relasi dan atrbutnya untuk mendesain relasi antar entitas.

1. Relasi antar entitas user dengan stock barang lab. dengan relasi peminjaman barang pada sistem dapat dilihat pada Entity Relationship Diagram yang ditunjukkan pada Gambar 3.4

i) Relasi Peminjaman dan Atributnya

Tabel relasi peminjaman ini berasal dari relasi peminjaman yang berdasar pada Data Flow Diagram Level 1 Proses 6 maka dibutuhkan atribut.
Atributnya akan dijabarkan seperti dibawah ini.

Tabel 3.5 atribut relasi peminjaman

\begin{tabular}{|l|l|}
\hline No & Atribut \\
\hline 1. & nama \\
\hline 2. & nim \\
\hline 3. & hp \\
\hline 4. & KodeBarang**) \\
\hline 5. & NamaBarang \\
\hline 6. & KodePinjam $*)$ \\
\hline 7. & TanggalPinjam \\
\hline 8. & TanggalKembali \\
\hline 9. & NamaLab \\
\hline
\end{tabular}

Pada relasi koneksifitas peminjaman ini atributnya terdiri dari nama peminjam, nim pemninjam, $\mathrm{cp}$ peminjam, kode barang yang dipinjam sebagai primary keynya, nama barang yang dipinjam, kode pinjam sebagai foreign key, tanggal kembali barang, dan terakhir adalah asal lab.

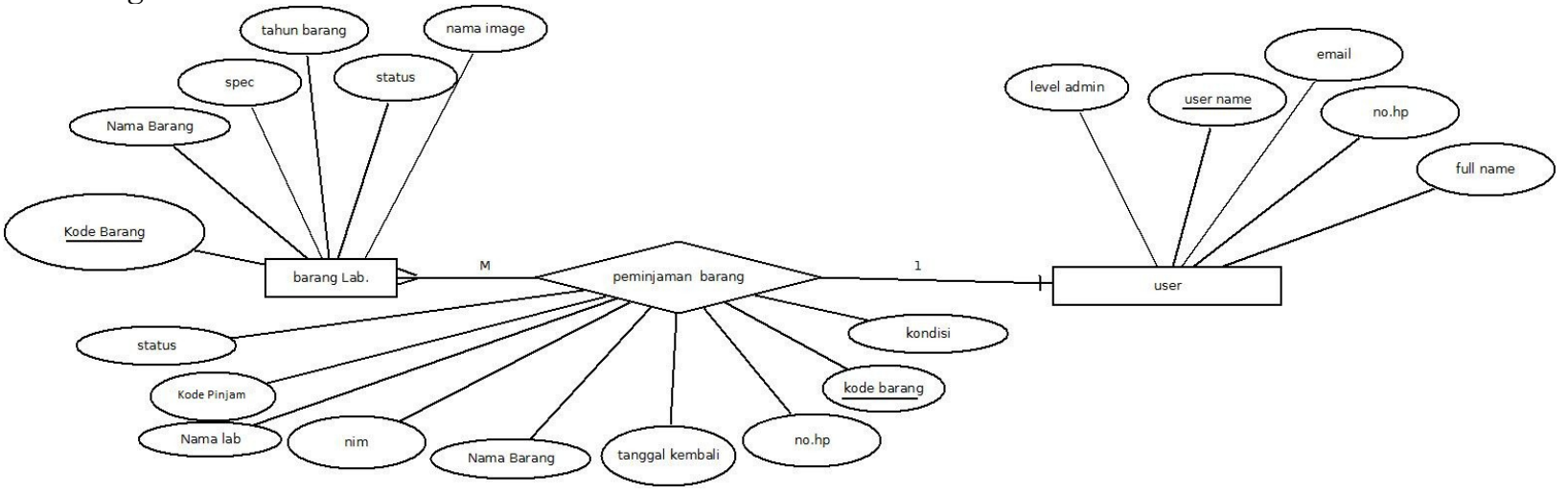

Gambar 3.4 ERD peminjaman barang

Pada Gambar 3.4 dapat terlihat bahwa hubungan entitas user dengan stock barang lab, memiliki kardinalitas one to many, dikarenakan satu user dapat melakukan banyak transakski peminjaman barang.
2. Relasi antar entitas user dengan stock barang lab. dengan relasi pengembalian barang dapat dilihat pada Entity Relationship Diagram yang ditunjukkan pada Gambar dibawah ini. 


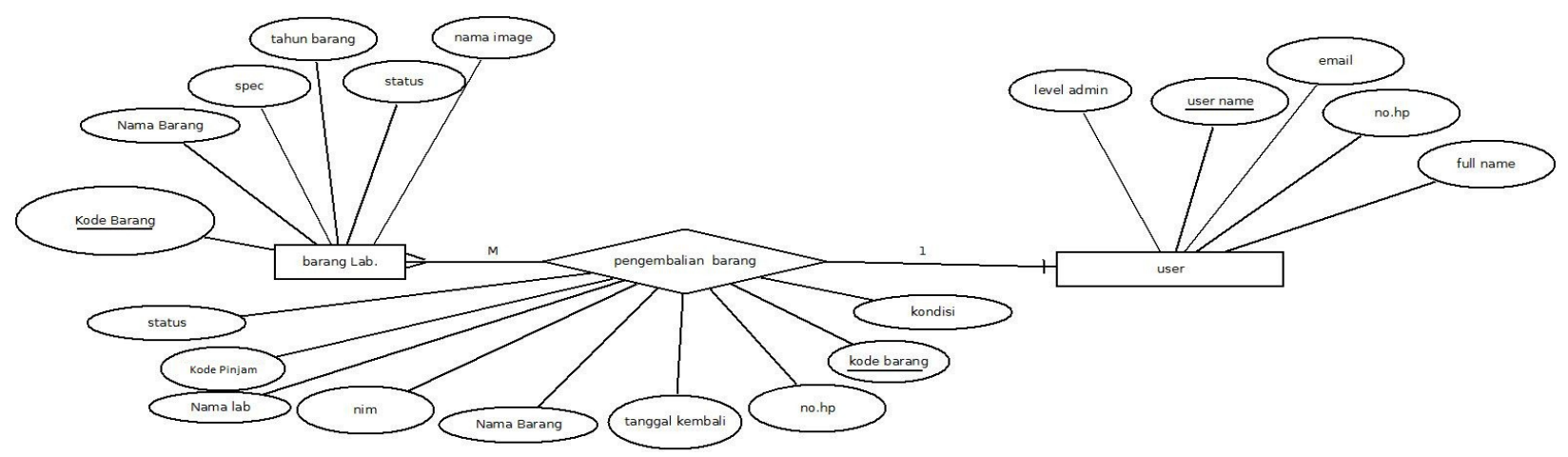

Gambar 3.5 ERD pengembalian barang

Pada Gambar 3.5 dapat terlihat bahwa hubungan entitas user dengan stock barang lab, memiliki kardinalitas one to many, dikarenakan satu user dapat melakukan banyak proses pengembalian

ii) Relasi Pengembalian dan Atributnya

Tabel relasi pengembalian ini berasal dari relasi pengembalian dibutuhkan atribut.

Tabel 3.6 atribut relasi pengembalian

\begin{tabular}{|l|l|}
\cline { 2 - 2 } & No Atribut \\
\hline & nama \\
\hline & nim \\
\hline & hp \\
\hline & KodeBarang $*$ ) \\
\hline & NamaBarang \\
\hline & TanggalPengembalian \\
\hline & Status \\
\hline & Kondisi \\
\hline
\end{tabular}

Pada relasi konektifitas pengembalian barang ini atributnya terdiri dari nama peminjam, nim pemninjam, cp peminjam, kode barang yang dipinjam sebagai primarykeynya, nama barang yang dipinjam, tanggal pengembalian barang yang telah disepakati dari kedua belah pihak, status barang apakah sudah dikembalikan atau belum, dan terakhir adalah kondisi barang ketika dikembalikan, apakah dalam kondisi baik atau cacat.

\section{PENGUJIAN SISTEM}

Pengujian Sistem Informasi inventory dan peminjaman dapat dilihat pada tabel 4.1 Pengujian aplikasi dibawah ini :

Tabel 4.1 Pengujian aplikasi

\begin{tabular}{|c|c|c|c|}
\hline $\begin{array}{c}\text { Nama } \\
\text { Pengujian }\end{array}$ & $\begin{array}{c}\text { Bentuk } \\
\text { Pengujian }\end{array}$ & $\begin{array}{c}\text { Hasil Yang } \\
\text { Diharapka } \\
\mathbf{n}\end{array}$ & $\begin{array}{c}\text { Hasil } \\
\text { Pengujia } \\
\mathbf{n}\end{array}$ \\
\hline $\begin{array}{c}\text { Pengujian } \\
\text { Login }\end{array}$ & $\begin{array}{c}\text { Memasukka } \\
\mathrm{n} \text { username } \\
\text { dan } \\
\text { password }\end{array}$ & $\begin{array}{c}\text { Muncul } \\
\text { tampilan } \\
\text { halaman } \\
\text { utama }\end{array}$ & Berhasil \\
\hline
\end{tabular}




\begin{tabular}{|c|c|c|c|}
\hline $\begin{array}{l}\text { Pengujian } \\
\text { Menu Buat } \\
\text { User Baru }\end{array}$ & $\begin{array}{c}\text { Menambah } \\
\text { user baru }\end{array}$ & $\begin{array}{c}\text { Muncul } \\
\text { tampilan } \\
\text { buat } u \text { ser } \\
\text { baru }\end{array}$ & Berhasil \\
\hline $\begin{array}{l}\text { Pengujian } \\
\text { Menu } \\
\text { operator lab. } \\
\text { Embedded }\end{array}$ & $\begin{array}{c}\text { login } \\
\text { dengan } \\
\text { username } \\
\text { operator } \\
\text { lab. } \\
\text { embedded }\end{array}$ & $\begin{array}{c}\text { Muncul } \\
\text { tampilan lab } \\
\text { embedded }\end{array}$ & Berhasil \\
\hline $\begin{array}{l}\text { Pengujian } \\
\text { Menu } \\
\text { operator lab. } \\
\text { networking }\end{array}$ & $\begin{array}{c}\text { login } \\
\text { dengan } \\
\text { username } \\
\text { operator } \\
\text { lab. } \\
\text { networking }\end{array}$ & $\begin{array}{c}\text { Muncul } \\
\text { tampilan lab } \\
\text { networking }\end{array}$ & Berhasil \\
\hline $\begin{array}{l}\text { Pengujian } \\
\text { Menu } \\
\text { operator lab. } \\
\text { software }\end{array}$ & $\begin{array}{c}\text { login } \\
\text { dengan } \\
\text { username } \\
\text { operator } \\
\text { lab. } \\
\text { software } \\
\end{array}$ & $\begin{array}{c}\text { Muncul } \\
\text { tampilan lab } \\
\text { software } \\
\text { engineer }\end{array}$ & Berhasil \\
\hline $\begin{array}{l}\text { Pengujian } \\
\text { Menu } \\
\text { peminjaman }\end{array}$ & $\begin{array}{l}\text { Mengklik } \\
\text { menu } \\
\text { jadwal TA }\end{array}$ & $\begin{array}{c}\text { Muncul } \\
\text { tampilan } \\
\text { jadwal TA } \\
\text { mahasiswa }\end{array}$ & Berhasil \\
\hline $\begin{array}{l}\text { Pengujian } \\
\text { Menu } \\
\text { pengembalian }\end{array}$ & $\begin{array}{l}\text { Mengklik } \\
\text { menu berita }\end{array}$ & $\begin{array}{c}\text { Muncul } \\
\text { tampilan } \\
\text { menu berita } \\
\text { beserta } \\
\text { judul dan isi }\end{array}$ & Berhasil \\
\hline $\begin{array}{l}\text { Pengujian } \\
\text { Menu history } \\
\text { peminjaman }\end{array}$ & $\begin{array}{l}\text { Mengklik } \\
\text { menu } \\
\text { unggah dan } \\
\text { memilih } \\
\text { file yang } \\
\text { akan } \\
\text { diunggah } \\
\end{array}$ & $\begin{array}{c}\text { Muncul } \\
\text { tampilan } \\
\text { menu unggah } \\
\text { data } \\
\text { berformat } \\
\text {.pdf dan .jpeg }\end{array}$ & Berhasil \\
\hline $\begin{array}{c}\text { Pengujian } \\
\text { Menu Cetak } \\
\text { Data }\end{array}$ & $\begin{array}{l}\text { Mengklik } \\
\text { menu Cetak } \\
\text { Data }\end{array}$ & $\begin{array}{c}\text { Muncul } \\
\text { menu cetak } \\
\text { data beserta } \\
\text { data yang } \\
\text { akan di } \\
\text { cetak } \\
\end{array}$ & Berhasil \\
\hline
\end{tabular}

\section{PENUTUP}

\subsection{Kesimpulan}

Dari hasil pengujian dan analisis aplikasi Sistem Informasi Laboratorium Sistem Komputer ini, maka dapat disimpulkan hal-hal sebagai berikut.

1. Sistem Informasi Sistem Informasi Laboratorium Sistem Komputer bermanfaat untuk memantau informasi dan data-data yang dimiliki oleh Program Studi Sistem Komputer berupa data barang yang masuk (baru) ataupun data barang yang keluar (ada atau dipinjam).
2. Aplikasi Sistem Informasi Laboratorium Sistem Komputer ini, memiliki empat hak akses yaitu sebagai super admin,Operator Lab.Embedded, Operator Lab. Networking, dan Operator Lab.Software Engineeer hal ini dikarenakan sebagai alasan keamanan, jadi masing-masing Operator tidak bisa mengakses satu sama lainnya.

3. Sistem Informasi Laboratorium Sistem Komputer ini menggunakan prinsip paperless namun tidak menghilangkan etika simpan pinjam barang Laboratorium.

\subsection{Saran}

1. Aplikasi Sistem Informasi Inventory dan Peminjaman Barang Pada Laboratorium Sistem Komputer Akhir ini dapat dikembangkan lebih lanjut dengan memberikan sistem "sms gateaway" dimana aplikasi akan menguhubungi dengan mengirimkan teks sms secara otomatis pada peminjam yang telat mengembalikan barang.

2. Melakukan backup data pada tabel history peminjaman, agar user tetap memiliki data history peminjaman, meski terjadi kerusakan pada sistem.

3. Menambah tabel "blacklist" yang berisikan peminjam barang laboratorium yang tidak bertanggung jawab (mengembalikan selalu telat, pernah merusak fasilitas lab dan lain sebagainya yang bersifat merugikan.

\section{DAFTAR PUSTAKA}

[1] Madcoms. Aplikasi Program PHP dan MySql, Penerbit Andi, Yogyakarta, 2004.

[2] Kadir, Abdul. Dasar Pemrograman Web Dinamis Menggunakan PHP. Penerbit Andi, Yogyakarta, 2008.

[3] M, David, Dasar-Dasar Desain Dan Implementasi Database Processing, Erlangga, Jakarta, 2005.

[4] Ladjamudin, Al Bahra Bin, Analisis dan Desain Sistem Informasi, Penerbit Graha Ilmu, Yogyakarta, 2007.

[5] Hakim, Lukmanul, Membokar trik Rahasia Para Master PHP, Loko media, Yogyakarta, 2008.

[6] Kadir, Abdul, Dasar Perancangan dan Implementasi Database Relasional, Andi Ofset, Yogyakarta, 2008.

[7] Kristanto, Andri, Perancangan Sistem Informasi dan Aplikasinya, Gaya Media, Yogyakarta, 2008.

[8] Nugroho, Bunafit. Latihan Membuat Aplikasi Web PHP dan MySQL dengan Dreamweaver, Gaya Media, Yogyakarta, 2008.

[9] Hakim, Lukmanul, Jalan pintas menjadi master PHP, Loko media, Yogyakarta, 2009.

[10] Hermawan, C.Widya, ShortCourse : PHP Programming, Wahana Komputer, Semarang, 2009.

[11] Kadir, Abdul, Form Zero tO A Pro Membuat aplikasi Web dengan PHP dan Database MySQL, Penerbit Andi, Yogyakarta, 2009. 
[12] Kadir, Abdul, Mastering AJAX dan PHP, Andi Offset, Yogyakarta, 2009.

[13] Kadir, Abdul, Mudah Mempelajari Database MySQL, Penerbit Andi, Yogyakarta, 2009.

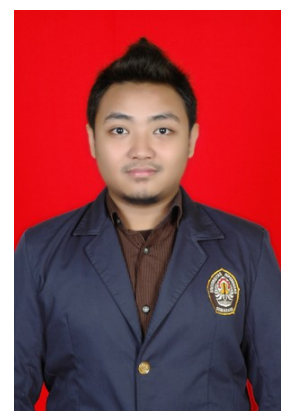

\section{BIODATA PENULIS}

\section{Rifky Rajendra}

Lahir di Bandung 6 Agustus 1990. Menjalani pendidikannya di Sekolah Dasar Negeri Srondol 02 Semarang, Sekolah Menengah Pertama Negeri 27 Semarang, Sekolah Menengah Atas Negeri 4

Semarang. Sekarang tengah menyelesaikan pendidikan Strata Satu di Jurursan Teknik Sistem Komputer, Universitas Diponegoro, Semarang angkatan 2008.

Menyetujui,

Dosen Pembimbing I

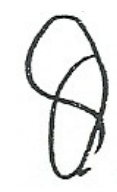

Ir. Kodrat Iman Satoto, M.T. NIP. 197302261998021001

Dosen Pembimbing II

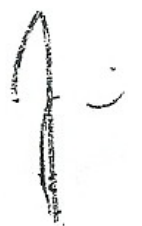

Rinta Kridalukmana, S.KOM., M.T.

NIP. 197706152008011011 